\title{
Questions of method in James Dunn's Jesus Remembered
}

\author{
Bengt Holmberg \\ University of Lund, Faculty of Theology \\ Allhelgona Kyrkog 8, SE-223 62 LUND \\ bengt.holmberg@teol.lu.se
}

James Dunn has managed to encapsulate a fundamental methodological perspective in the very title of his impressive and important book on the historical Jesus - Jesus Remembered. ${ }^{l}$ In the book Dunn states forcefully that we have to reimagine what type of material the gospels are. The gospels should not be seen as equivalents of an archaeological tell, where each textual layer builds upon and changes the preceding one. The many oral and later written retellings then function as so many filters between us and the original event, leaving the historical Jesus almost unrecoverable. This $20^{\text {th }}$ century piece of scholarly orthodoxy is a misunderstanding of how oral tradition works, and how the gospels use it. Oral tradition has a direct relation to memory, being shaped by it from the very start. Each version, or "performance," of the oral tradition may be different from others, but retains the core elements given in the start. This means that we are at roughly the same, fairly close distance from the original memory in all the variant performances - Mk, Q, special Luke, etc. Compared to other views in this discipline, the distance between us gospel readers and the original memory about Jesus has lessened considerably in Dunn's view.

The other and resulting part of this methodological perspective is formulated by Dunn as the following principle: "The only realistic objective for any 'quest of the historical Jesus' is Jesus remembered" (pp. 335 and 882). This means that a historian cannot aim at getting hold of anything like "wie es eigentlich gewesen ist" in regard to the historical Jesus. The nearest we can get to this object is the memories of him, and in Jesus research too we have to say farewell to the old dream of reaching an objective, historically secure level of event as opposed to interpretation. This goes for all historical work, of course, which always operates with data resulting from events but not the events themselves. The typical form of historical data is memories, usually arranged in narrative sequence.

So, a natural starting point for discussing questions of method in Dunn's book is what is meant by memory and remembering, and what is meant by "Jesus remembered".

\section{The role and meaning of memory.}

I will leave aside any discussion of to what degree memory is an interpretation of things seen and heard, and suggest straight away that the term "memory" includes a statement or claim concerning a notable correspondence or "fit" between the event and memory's mental image of it. A person who was not present at a specific event may subsequently acquire knowledge even good, accurate knowledge - about it from others, but he does not in normal parlance have any memory of it. In a transferred meaning we can talk about children sharing their

\footnotetext{
${ }^{1}$ James D.G. Dunn, Jesus Remembered (Christianity in the Making, vol. 1; Eerdmans: Grand Rapids, 2003).
} 
parents' childhood memories, or about the church's memory of Jesus, but this "sharing" is really shorthand for being told about other people's memories.

We don't become naive realists or positivists by thinking about "memory" as corresponding in some degree to experienced reality, acknowledging, of course, that there is no such thing as a complete, neutral and objective fit between the event and what is remembered of it. But the term "memory" is not synonymous with simply any mental content, and even less with "fond imagination", but conveys the idea of more or less accurate memory of something witnessed by the one who remembers. Memories are carried around by human beings, whose perception and knowledge and interpretation even of matters they have experienced is inevitably partial and subjectively coloured. But what they remember is a reality that exists outside their own minds, even if their memory is a distorted picture of that reality.

What is remembered is articulated, retold to others and thereby to oneself, most often by being given a narrative form. The narrativisation of what is remembered is a natural, almost inevitable process of the human mind. When the role of memory building in historiography is considered, we realise, says Jens Schröter, that the distinction between res fictae and res factae is not as clear-cut as in Aristotle's thinking about the difference between poets and historians. When we are doing historiography, we are really "fictionalising" historical facts, ${ }^{2}$ i.e. giving historical facts a narrative form, which is the standard, "natural" form of doing history, or in other words: knowing about the past. There is no other way to grasp historical reality than "the meaningful narrative of events and intentions". ${ }^{3}$ We are "refiguring" (Schröter) a memory, but what we are fictionalising about is the events themselves, and our work is bound to the data provided by our sources. Refiguring memory is not the same as disfiguring it.

This is a point made by Dunn too - memory is not simply what people choose to remember. In his important chapter 10, where he summarises his previous three hundred pages of methodological discussion, Dunn writes:

If the Synoptic tradition does not give us direct access to Jesus himself, neither does it leave us simply in the faith of the first-century Christian churches stopped well short of that goal. What it gives us rather is the remembered Jesus - Jesus not simply as they chose to remember him, but also as the impact of his words and deeds shaped their memories and still reverberated in their gatherings (p. 328).

Dunn differs from other questers in (1) his "claim that we can get back to the earliest impact made by Jesus", because (2) "the impact translated itself into community tradition from the first", which comes close to meaning - if I get Dunn right - that Jesus himself is the creative impact and the tradition-originating impulse (p. 329). The event itself impacts the memory and constrains or creates the core and the limits of what is remembered. In other words, the memory that shaped the Jesus tradition is a fairly "accurate" or realistic memory that

\footnotetext{
${ }^{2}$ Jens Schröter, 'Die Frage nach dem historischen Jesus und der Charakter historischer Erkenntnis', in Andreas Lindemann (ed.), The Sayings Source $Q$ and the Historical Jesus (BETL 158; Leuven 2001) 207-254; here pp. $228-33$.

${ }^{3}$ N.T. Wright, The New Testament and the People of God (Christian Origins and the Question of God, vol. 1; Fortress: Minneapolis, 1992) 82.
} 
corresponds well with what actually took place. Generally speaking, the impression given in Dunn's book as a whole is that historians researching Jesus do not have to grope for their object in a pea soup fog - something real is visible This is not to deny that the tradition has been elaborated, only that this later elaboration has not obliterated the originating impulse. We almost touch Jesus himself in the Jesus tradition.

\section{What is the object of historiography - events or early fictionalizations of the events (memories)?}

But we have to go on. What is meant when Dunn writes: "The only realistic objective for any 'quest of the historical Jesus' is Jesus remembered"? I understand the word "objective" here as synonymous with "aim, intention, goal", rather than with "object, thing, entity, matter treated". The fact that "objective" could mean both necessitates some further discussion.

Perhaps it is helpful to make a distinction here between (A) the stuff or material available for historical study, "what we are looking at in the Jesus tradition" (p. 332), which one has to agree with Dunn in characterising as the memories of Jesus, the remembered Jesus, and (B) "what we are looking for through the Jesus tradition" (p. 332), the object of historical study, the thing we want to know and say something true about, which is Jesus himself. Do we - and Dunn - when doing historical work on Jesus focus only on (A), or is also (B) included?

In the beginning of chap. 12 on the Kingdom of God in the Jesus tradition, Dunn shows that this motif is frequent in the Synoptic Gospels, while it is not very prominent in contemporary Judaism or in early Christian texts. He concludes:

The prominence of the kingdom motif in the Jesus tradition cannot be explained as a reflection of a similar prominence of the motif within either the Judaism of Jesus' day or the teaching of the early churches. Once again, we have little choice but to attribute the prominence of the motif in the Jesus tradition to a memory of (my italics) its prominence in Jesus' own teaching and preaching (p. 386).

The insertion of the phrase "a memory of" actually seems superfluous. Is not Dunn really stating that the kingdom motif is so prominent in the Jesus tradition because Jesus used it frequently? I.e. he seems actually to make a statement, not only about how people remembered Jesus, but about Jesus himself as he was, which makes me wonder if "the remembered Jesus" only refers to (A) the tradition about Jesus, or also to (B) Jesus himself? If Dunn had used the term "the imagined Jesus" or "the fictionalised Jesus", one would have concluded that he was referring to (A) only. But the terms "memory" and "remember" seem inevitably to pull (B) into the scope of the designation "the remembered Jesus", as is evidenced in many places in this book (e.g. the whole of chapter 16 on how Jesus viewed his own role). I am not sure whether this is intended by Dunn, or the result of a methodological decision that has not held up against the pressure of research tradition and the natural historical curiosity of wanting to know about and state things about Jesus himself. 
A further question concerning memory as a historiographical key concept is: Does the recognition that we are treating memories obliterate or impede the historiographical task of forming probability judgments concerning the subject investigated? According to critical realism in the Lonergan - Meyer - Wright tradition of historiography (which Dunn tentatively aligns himself with on p. 111) one should not be satisfied as historian until one has reached a judgment on historical fact.

Dunn seems sometimes to be content too early in that historical process. He settles for reaching the earliest accessible, oral "layer" (a term he repudiates, to be sure) of tradition which is caused by the impact of the event. When summarising his discussion on the miracles of Jesus he writes:

... there are no objective events of people being healed, no non-miracles to be uncovered by clearing away layers of interpretation. All we have in at least many cases is the shared memory of a miracle which was recounted as such more or less from the first day. What the witnesses saw was a miracle, not an 'ordinary' event which they interpreted subsequently as a miracle. There must have been many who experienced Jesus' ministrations to them as miracles, individuals who were genuinely healed and delivered, and these successes were attributed there and then to the power of God flowing through Jesus. Only so could Jesus' reputation as exorcist and healer have become so firm and so widespread so quickly. In such cases, we may say, the first 'historical fact' was a miracle, because that was how the event was experienced ... by the followers of Jesus who witnessed it (pp. 672-73).

What has Dunn said here? That a formerly, say, lame person now can walk freely and attributes this change to Jesus having worked a miracle on him. We have reached the remembered Jesus, and formed a judgement on the character of the evidence, namely that the report articulating this memory was always a miracle story. This earliest level, Dunn contends energetically and in many places in his book, is not overlaid by many subsequent layers of editing, i.e. of written versions, each one an interpreting edition of the preceding one. The impact that created the tradition lives on in an oral form which varies naturally between different performances of it, but all of which are in their core equally close to the originating impact.

But the question of any critical realist historian is: have we by stating this actually moved from a characterisation of the material as impacted by Jesus (I think Dunn has a good case there: miracle stories were stories about miracles from day 1) to the desired end result of historical study on Jesus, namely Jesus himself? Can we, or can we not, conclude anything about the event itself, e.g. that the reported healing really occurred and that Jesus really had what people believed him to have: the power to heal? Dunn starts with a negative answer at the beginning of the quotation above, but then talks of individuals genuinely healed. This is not an unreasonable conclusion, but is it concordant with Dunn's stated method and object of historical research?

I contend that we have not completed our work as historians working on Jesus unless we push forward from the statement that a certain motif, say, the kingdom motif, appears frequently in 
the Jesus tradition because that was how Jesus was remembered to have spoken, to a judgment about whether he actually spoke like that or not. The historiographical task is not finished until we have reached beyond a judgment about reported history (people's memory of Jesus is that he worked miracles) to a judgment on the report's degree of correspondence with reality, or in other words, its historical facticity (Jesus did not work miracles, and what people remembered was mistaken from day 1 . Or he did).

At other times Dunn is not averse to attempting the second step in historical work, to push on from the Jesus tradition in its earliest reachable form to the person this tradition is about, Jesus himself. We find this several times, e.g. in chs 9, 13, 16 and 17. On p. 489 Dunn takes up Reimarus' question "What was Jesus' intention?", and in the opening of ch. 16 (on how Jesus saw his own role) he can write:

It remains important to bear in mind my primary focus on the impact made by Jesus. But in this case it is necessary to hazard the next step, the difficult task of attempting to trace out, by reference to the 'shape' of the impact made by Jesus, the 'shape' of what made that impact ${ }^{4}$ - that is, what Jesus may have said or indicated about his own perception regarding his own role which has resulted in such features of the Jesus tradition (p. 705).

If it is possible to investigate the "shape" of Jesus (who impacted other people) in this area of his life and work, why not in every area? Why not aim at pushing consistently forward from level A (reaching judgments on the memories) to level B (making probability judgments about historical facticity)? Should it not be part of Dunn's consistent methodology to "hazard the next step"?

\section{What are historical facts?}

Dunn, following Collingwood, Ben Meyer, and Tom Wright, would answer: historical facts are interpretations of data. Leaning on Collingwood, Dunn states succinctly (pp. 102-103) that the historical event belongs to the irretrievable past, the data (personal memories, reports from eyewitnesses, etc) are what remains, from which the historian attempts to reconstruct the facts. Facts are always interpretations of data and can only approximate the event itself, never become identical with it. Abundant and consistent data permit close approximation between event and historical facts, while few and contradictory data leave us with very little material for interpretation and consequently very few facts, stranding us far from the event. The degree of proximity between event and historical fact is expressed in degrees of probability, and it is to be considered a great step forward in historical research to say about anything that it is probable.

So, we begin with data and arrive at facts, through a process of interpretation. Data have to be interpreted, i.e. selected, construed, put together in a pattern that makes them meaningful, and so become historical facts. This is not a random process, however. There are scores of theoretically thinkable or possible patterns, which when screened through filters of historical

\footnotetext{
${ }^{4}$ Dunn himself refers here to a previous statement on p. 616: "My own emphasis on the impact made by Jesus also does not necessarily close off the road to Jesus' self-understanding. For the clearer the impression made, the clearer the object making the impression."
} 
verification are narrowed down to a few plausible or reasonable hypotheses about how these data are to be related to each other. The historian's task is to falsify all hypotheses, one by one, until one of them cannot be refuted, i.e. is verified as a probable answer to the historical question. (This is Ben Meyer's way of describing the historical interpretation process in the first part of his The Aims of Jesus). ${ }^{5}$ So, the historian starts with data, works with questions and answers in the form of hypotheses that cover all the data, moving in a rigorous sifting process from the many thinkable hypotheses, over the few plausible ones, and arriving, in the best cases, at historical fact, i.e. the most probable hypothesis.

But there are different kinds of facts, as can be exemplified from Dunn's chapter on the resurrection (ch. 18). Dunn emphasizes many times that the historian's task cannot be to get hold of some objective, 'factual' history behind the remembered and interpreted one. Data are always interpreted, i.e. selected, construed, put together in a pattern that makes them meaningful, and so become historical facts.

If historical facts are interpretations of the data, then the historical facts in this case [the resurrection of Jesus], properly speaking, are at best the fact of the empty tomb, and the fact that the disciples saw Jesus. The conclusion, 'Jesus has been raised from the dead', is further interpretation, an interpretation of interpreted data, an interpretation of the facts. The resurrection of Jesus, in other words, is at best a second order of 'fact', not a first order 'fact' —an interpretation of an interpretation (p. 877).

Interpretation of data can mean different things, though, as can historical facts. In this short citation we encounter three kinds of fact: the fact of the empty tomb, the fact of the disciples seeing Jesus, the fact that Jesus is risen from the dead and somehow alive again.

Sometimes to "interpret" data is very close to "conclude" from them, leaving very little to subjectivity. If a person entered the tomb of Jesus on the fourth day after the entombment and then interpreted the lack of a corpse as the historical fact of an empty tomb, this can not be described as a highly subjective and purely personal interpretation. In other cases, however, "interpreting data" means something much more personal, rich in emotion and reminiscence that can hardly be formulated in words or communicated in understandable form to others. Historical interpretation as a scholarly discipline is much closer to the former than to the latter kind of interpretation, and its distinguishing mark is its high degree of intersubjectivity, i.e. its character of being available and even equally compelling to other people. The three different kinds of fact mentioned above have very different degrees of intersubjectivity.

The terminology used here of "data", "interpretation", and "facts" hides an important distinction between historical facts that can be contested and facts that can't. Of course the fact of the empty tomb is built up - like any historical fact - of sense perception data, from which it is concluded that the tomb is empty. But that conclusion, once formed, could not be disconfirmed or put into doubt by the interpretations of others - if the tomb was empty, it was empty for everyone to see, not just for the disciples who saw it first. The empty tomb is a fact that once established does not allow of further disconfirmation. This is not the case with the next kind of "fact", of the disciples seeing Jesus. While undeniable to the disciples, it is

\footnotetext{
${ }^{5}$ Ben F. Meyer, The Aims of Jesus. SCM: London, 1979.
} 
simply inaccessible to bystanders and cannot be called forth by simple observation. This is not to say that it is unreasonable for a historian to conclude that the disciples really "saw" something which they in good faith believed strongly to be Jesus alive. But the nature of the case does not allow any confirmation or disconfirmation of the truth of that belief itself. And what about the third kind of fact? Is it even possible to state clearly what it means that Jesus was raised from the dead, if some find that statement consonant with the idea that Jesus' corpse is still lying somewhere under the Old City of Jerusalem, while others claim that it must mean that Jesus, body and soul, entered another and higher type of reality, inaccessible to any human observation and therefore altogether outside the grasp of historical research and the category of historical fact?

One can also think of intermediate cases, where (part of) the data are accessible to anyone present, but the interpretations differ, and consequently also the historical fact(s). Are we therefore to conclude that all historical interpretations of an event are of equal value, and enjoy equal probability and equal facticity? Are we not rather obliged as historians to argue about which of the offered historical facts/interpretations has the claim of highest probability?

How are we then helped by Dunn's distinction between "historical fact" (which the resurrection is not) and "foundational fact or meta-fact" (which the resurrection must be characterised as) on p. 878 ?

\section{The methodological role of grand narratives}

Grand narratives are also called "meta-narratives", "master narratives", or "controlling stories". The term refers to large-scale interpretative paradigms underlying historical reconstruction, such as the master narrative of development and progress as the self-evident way in which to understand history. ${ }^{6}$ A "self-evident" master narrative in older Jesus research was that Jesus wanted to break with Judaism and establish a law-free religion, open for everyone, or at the very least that he was very different from the surrounding Judaism. Today one might say that the master narrative characterising the Third Quest is more or less the opposite: Jesus must belong within the Judaism of his own time if he is to be historical at all.

Dunn criticizes Crossan's and Wright's attempts at interpreting the Jesus data from an overarching 'grand narrative' (pp. 470-477), but the rightness of his criticism concerns more the specific models proposed by them than the method itself of using a master narrative as a frame of interpretation. Certainly a grand narrative should have a good fit with everything known about the historical context of the object and be worked out in a responsible, i.e. testable manner. That is where Crossan and Wright can be criticized. Crossan's "peasant" Jesus does sit rather loose to what is known about first-century Jewish village life in Galilee, and so does Wright's 'return from the exile'-paradigm in relation to extant sources and the gospels themselves. Even if Dunn's criticism of Crossan's and Wright's grand narratives is effective, it does not warrant his conclusion that one shouldn't use grand narratives at all in

\footnotetext{
${ }^{6}$ See the work of Appleby, Hunt, and Jacob, Telling the Truth About History, New York 1994, as discussed by Halvor Moxnes, "The Historical Jesus: From Master Narrative to Cultural Context", in Biblical Theology Bulletin 28 (1998), 135-149.
} 
historical reconstruction. This seems to me to amount to throwing out the baby together with the bathwater.

This mistrust against grand narratives doesn't seem to square with Dunn's methodological decision to "look first at the broad picture" (p. 332), and use what Telford called the 'holistic' method. So, one feels here the need of a discussion why Dunn bans the grand narrative as method when his method otherwise is to "focus attention on characteristic features / themes in the Jesus tradition and not linger long over particular sayings or episodes or make an emerging portrayal of an aspect of Jesus' mission overly dependent on one or two pericopes" [an error Dunn finds in many other scholars' work] (p. 335). Dunn normally sides with the many scholars today who find it more historically adequate and methodologically fruitful when reconstructing the Jesus of history to start with the "Gestalt", the whole figure of Jesus, a vast and complex but coherent image of what Jesus wanted or aimed at, than - as did the Second Quest - starting in the details (individual sayings and episodes) and try to establish a critically sifted and secured minimum of authentic material, on which to build the rest of their historical reconstructions. The very scope of Dunn's work indicates that he wants to settle for nothing less than completeness in his picture of Jesus, answering all questions that should be asked.

Tom Wright has made the claim that there are a number of questions, or rather, a set of questions, all of which a knowledgeable and responsible historian has to ask about Jesus.

[I]n fact, no work on Jesus can get off the ground without a position being taken, at least by implication, in relation to them all... The five questions are all subdivisions of the larger question which, I submit, all historians of the first century, no matter what their background, are bound to ask, namely: how do we account for the fact that, by AD 110, there was a large and vigorous international movement, already showing considerable diversity, whose founding myth (in a quite 'neutral' sense) was a story about one Jesus of Nazareth, a figure of the recent past? ${ }^{7}$

Wright then formulates the questions that all historians have to answer:

(1) How does Jesus fit into the Judaism of his day?

(2) What were his aims?

(3) Why did he die?

(4) How did the early church come into being, and why did it take the shape it did?

(5) Why are the gospels what they are?

Any serious historian must attempt to answer all of these questions, in order to avoid too narrow and one-sided hypotheses and the skewed results inevitably following from them. ${ }^{8}$

These questions are fairly similar to the ones formulated recently by Gerd Theissen and Annette Merz, but actually going back to Reimarus (†1768). They are:

(1) How dependable are the sources about Jesus?

(2) How Jewish is the historical Jesus?

\footnotetext{
${ }^{7}$ N.T. Wright, Jesus and the Victory of God (Christian Origins and the Question of God, vol. 2; Fortress: Minneapolis, 1996), 90.

${ }^{8}$ Wright, Jesus and the Victory of God, 90.
} 
(3) How political is the historical Jesus?

(4) How eschatological is the historical Jesus?

(5) How christological is the historical Jesus?

A sixth question that Reimarus did not ask is added:

(6) How alien is the historical Jesus? which could also be phrased: How much have we modernized the historical Jesus? ${ }^{9}$

It is not hard to see that Wright's questions 1-3 have the same content as Theissen and Merz's questions 2-5. And Dunn's book treats the same questions, although he too defers the treatment of questions concerning the early church to coming volumes of his work, just like Wright. Question one, the way that Jesus fits into the Judaism of his day, is taken up in chs 9 and 11 of Dunn's book, in which he focuses on outward realities (Jesus' profession, education, homestead, relation to John the Baptist, etc.). The aim(s) of Jesus (Wright's question 2, Theissen and Merz's 3-5) are then investigated in the following chapters, almost to the end of Dunn's book. Chapter 12 on the Kingdom of God serves as a kind of portal for all other questions concerning Jesus' aims: for whom Jesus intended his message, and what reception of it would mean, how others understood Jesus and how he understood himself in relation to the kingdom, a question that can only be answered if one knows what Jesus thought of his death (chapters 13-17, pp. 489-824).

So, James Dunn has made a very thorough job of answering the complete set of questions, making the different answers build up a large and coherent picture of the historical Jesus. A grand narrative, as it were, that includes even the death of Jesus and what he meant by it, and that follows the gospels even by ending in his resurrection. Dunn concludes his discussion of this in ch. 18:

Despite the inconsistencies and tensions which the diversity of traditions evidences only too clearly, it is in the end of the day the tradition itself which pushes us to the conclusion that it was something perceived as having happened to Jesus (resurrection evidenced in empty tomb and resurrection appearances) and not just something which happened to the disciples (Easter faith) which provides the more plausible explanation for the origin and core content of the tradition itself (p. 876).

John P. Meier clearly thinks that it is impossible for a historian to discuss the resurrection (and to reach such a conclusion as Dunn above), and this difference of opinion about what questions can be asked in historiography is methodologically important. ${ }^{10}$ In the beginning of his recent book on the resurrection of Jesus, Tom Wright distinguishes between five different senses of "history":

1. History as event. What is 'historical' is what existed and really happened, whether we can prove it or not (such as the death of the last pterodactyl, never witnessed or

\footnotetext{
${ }^{9}$ Gerd Theissen and Annette Merz, 'Der umstrittene historische Jesus. Oder: Wie historisch ist der historische Jesus?', in Gerd Theissen, Jesus als historische Gestalt: Beiträge zur Jesusforschung. Zum 60. Geburtstag von Gerd Theissen herausg. v. Annette Merz (FRLANT 202; Vandenhoeck \& Ruprecht: Göttingen, 2003) 3-32; here pp. 3-7.

${ }^{0}$ John P. Meier, A Marginal Jew. Reconsidering the Historical Jesus, vol. I, Doubleday: Garden City, 1991.
} 
reported by any human, but concluded to from fossil remains, which do not admit of any other interpretation than that pterodactyls once lived and died on this earth).

2. History as significant event. "Geschichtlich", not only "historisch" (Bultmann).

3. History as provable event. "X may have happened, but we can't prove it, so it is not a historical fact". (This is a much narrower definition than 1 or 2).

4. History as historiography, written or oral; reported or reportable history.

5. History as that which can be stated by a historian within the modern, postEnlightenment, non-theistic worldview. ${ }^{11}$

It seems that while John P. Meier, constrained by his idea that history is what all competent scholars regardless of their religious belief can agree on, understands history as scholarly work of type 5 in Wright's list, Dunn does not. It makes one wonder if this difference in methodology and understanding of history could after all be formulated as a difference in relation to the use of grand narrative. Might not Dunn's large and coherent picture of Jesus be understood as something of a theistic, even Christian, grand narrative guiding all of his historical reconstruction of Jesus? It is certainly undertaken with great historical care, and is open to testing by others. But it looks for a history that makes sense of all the gospel data, which other scholars may characterise as an underlying conviction that functions as a "grand narrative": the story of Jesus as told by the gospels is a meaningful whole.

\footnotetext{
${ }^{11}$ See N.T Wright, The Resurrection of the Son of God (Christian Origins and the Question of God, vol. 3; Fortress: Minneapolis, 2003) 11-12 (not quoted verbatim).
} 